\title{
Article/Artigo
}

\section{Effects of flooding of the River Paraná on the temporal activity of Anopheles (Nyssorhynchus) darlingi Root (Diptera: Culicidae), at the border State of Mato Grosso do Sul and São Paulo, Brazil}

\author{
Efeitos do alagamento do Rio Paraná na atividade horária de Anopheles (Nyssorhynchus) darlingi \\ Root (Diptera: Culicidae), na divisa dos Estados do Mato Grosso do Sul e São Paulo, Brasil
}

\author{
Almério de Castro Gomes ${ }^{1}$, Marcia Bicudo de Paula ${ }^{1}$, Delsio Natal ${ }^{1}$, Sabina Léa Davidson Gotlieb ${ }^{1}$ \\ and Luis Filipe Mucci ${ }^{1}$
}

\begin{abstract}
Introduction: Study of the temporal activity of malaria vectors during the implantation of a hydroelectric power station on the River Paraná, intended to generate electrical energy. The river separates the States of São Paulo and Mato Grosso do Sul, in Brazil. The objective was to verify whether alterations occurred in the wealth and diversity indices of Anopheles, following two successive floods, extended to the temporal activity and nycthemeral rhythm followed over a five year period. Methods: Mosquito capture was performed monthly using the Human Attraction Technique and Shannon Traps. The first, executed for $24 \mathrm{~h}$, provided the nycthemeral rhythm and the second, lasting $15 \mathrm{~h}$, permitted the tracking of Anopheles during the two floods. Results: The bimodal pattern of Anopheles darlingi defined before these floods was modified throughout the environment interventions. The same effect had repercussions on the populations of An albitarsis s.l., An triannulatus and An galvaoi. Activity prior to twilight was less affected by the environment alterations. Conclusions: The dam construction provoked changes in Anopheles temporal activity patterns, permitting classification of the area as an ecologically steady and unstable situation. Differences observed in Anopheles behavior due to the capture methods revealed the influence of solo and multiple attractiveness inside the populations studied.
\end{abstract}

Key-words: Hydroelectric power station. Anopheles. Diversity index. Nycthemeral rhythm.

\begin{abstract}
RESUMO
Introdução: Estudo da atividade horária de vetores da malária durante a implantação de uma represa no Rio Paraná, destinada à geração de energia elétrica. O rio separa os Estados de São Paulo e Mato Grosso do Sul, no Brasil. O objetivo foi verificar se as alterações na riqueza e diversidades de Anopheles diante de duas inundações sucessivas se estendiam à atividade horária e ritmo nictimeral numa série temporal de cinco anos. Métodos: A captura de mosquito foi mensal, por meio dos métodos Técnica Atrativa Humana e Armadilha de Shannon. A primeira, executada durante 24 horas, forneceu o ritmo nictimeral e a segunda, com duração de 15 horas, para acompanhar os anofelinos durante as duas inundações. Resultados: O padrão bimodal de Anopheles darlingi definido antes dessas inundações foi alterado ao longo das intervenções ambientais. O mesmo efeito repercutiu nas populações de An albitarsis s.l., An triannulatus e An galvaoi. A atividade pré-crepuscular foi a menos afetada pelas alterações ambientais. Conclusões: As barragens provocam mudanças no padrão de atividade horária dos anofelinos permitindo classificar a área em situação ecologicamente estável e instável. Diferenças observadas no comportamento dos anofelinos pelos métodos de captura mostram a influência da uni e múltipla atratividade dentro das populações estudadas.
\end{abstract}

Palavras-chaves: Hidrelétrica. Anopheles. Índice de diversidade. Ritmo nictimeral.

1. Department of Epidemiology, School of Public Health, University of São Paulo, São Paulo, SP, Brazil. Address to: Dr. Almério de Castro Gomes. Depto de Epidemiologia/FSP/USP. Av. Dr. Arnaldo 715, 01246-904 São Paulo, SP, Brazil.

Phone: 5511 3061-7728

e-mail: bicudo@usp.br

Received in 18/12/2009

Accepted in 29/04/2010

\section{INTRODUCTION}

The loss of forests has influenced changes in the wealth, diversity and distribution of specimen of fauna and flora. Reflections concerning the diversity of the mosquito Culicidae have been postulated, with implications in transmission patterns, especially in malaria ${ }^{1}$. Nevertheless, few studies have been conducted regarding the population dynamics of Anopheles in areas recently altered, thus explaining why it is difficult predict the circumstances of maintenance and increase in plasmodium transmission among humans ${ }^{2}$.

The region where the study was developed has passed through an historic process of deforestation and development of cattle and diversified crops, existing among a vast complex of lakes. At present, the effects of the construction of the artificial lake of Porto Primavera intended to generate electricity stands out, altering the ecological and biological characteristics of Anopheles. Similar environmental impacts have already made evident the population revival of Culicidae mosquitoes ${ }^{3}$, among which are important primary and secondary vectors of malaria.

When a new composition of Culicidae forms, the process of changes imposes adaptation patterns that reflect in species behavior, until ecological interrelations stabilize. Temporal activity can be one of the characteristics affected and, in the case of dams, the factors that emerge during each of the phases of their construction have yet to be established. Given these facts, the spatial and temporal effects on the behavior of Anopheles species over a long-term capture series, comprising the beginning, duration and flowing the lake formation, remain unknown.

Anopheles (Nyssorhynchus) darlingi is the target of this research, since it is considered a primary vector for human plasmodium in Brazil. Some reports consider dams as factors of malaria transmission recrudescence in diverse landscapes ${ }^{4}$, such that is 
important to know which part of vector capacity is affected to take preventive measures against human infection ${ }^{5}$.

Anopheles (Nyssorhynchus) albitarsis, formed by a complex of four genetic varieties, is distributed in various geographic regions of Brazil $^{6}$, such that its status as a vector of malaria is arguable due to the variation in its vectorial competence, including in State of São Paulo 7 . In areas sympatric for $A n$ darlingi, its presence has been interpreted as an Anopheles auxiliary in plasmodium transmission ${ }^{8}$. For Santos and Forattini ${ }^{7}$, the low rate of species survival is compensate by its abundance, emphasizing that in the Ribeira Valley/São Paulo region, the risk of plasmodium transmission has been potentized by its massive presence in the area.

Given this context, the present study aimed to observe whether alterations in the of wealth and diversity indices, subjected to direct or indirect factors of the Porto Primavera Dam, reflect some kind of effect on the temporal activity of Anopheles.

\section{METHODS}

For this study, three areas were chosen: location $\mathbf{A}$, situated in the town of Bataguassu in the State of Mato Grosso do Sul, with no direct connection with the flooding; location $\mathbf{B}$, which suffered two successive floods; and location $\mathbf{C}$, which suffered only one, both located in the town of Presidente Epitácio in the State of São Paulo $^{9,10}$. This last location has no direct connection to the dam, since it is formed by a dam on the River Peixe, a tributary of the River Paraná . During the course of the dam project, from construction to the formation of the lake, entomological investigations consisted of three stages: stage 1 , the pre-flooding period at a surface water elevation (SWE) of $247 \mathrm{~m}$; stage 2, initial flooding reaching at SWE of $253 \mathrm{~m}$ and stage 3 , at a SWE of $257 \mathrm{~m}$.

The measurement of temporal activity was achieved by two methodological procedures. The method used for capturing adult mosquitoes was the Human Attraction Technique (HAT), involving a $24 \mathrm{~h}$ cycle, which determines the nycthemeral rhythm of Anopheles. This technique consists of two people waiting for mosquitoes to land on their outfit. The second technique used was the Shannon trap (ST), which has multiple attractive stimulations ${ }^{9,10}$.

In stage 1, captures in location A using HAT were conducted for the period from February 1998 to January 1999; captures using ST, in dawn twilight (dST), were conducted from January to November 1998; at location B, HAT was used from July 1997 to 1998 . In stage 2, at location A, captures with dST were conducted from January to November 1999; while at location B, HAT was used for the period from April 1999 to March 2000. The ST were used for $15 \mathrm{~h}$ (15h ST) for the period from April 2000 to February 2001. In stage 3, at location B, 15h ST was used from April 2001 to February 2002, and dST from March 2001 to February 2003, both in wild areas and peridomicile. At location $\mathbf{C}$, captures were conducted from April 2001 to February 2002 with 15h ST and from April 2001 to February 2003 with dST, in wild areas and peridomicile. Captures were performed for a period of one week each month and were conducted by two collectors dressed in proper outfits and gloves to protect against mosquito bites.

To understand the nycthemeral rhythm of Anopheles species, the $24 \mathrm{~h}$ period was broken down into one hour sections. Similarly, the $15 \mathrm{~h} \mathrm{ST}$ captures complemented the determination of temporal activity. These began at $5 \mathrm{pm}$ and ended at $8 \mathrm{am}$.
The Shannon trap was also used to measure the frequency of Anopheles during pre and post dawn twilight periods, when twilight captures consisted of $20 \mathrm{~min}$ interval, with segments defined as first and second pre twilight, twilight, first, second, third and fourth post twilight, between $5 \mathrm{pm}$ and $9 \mathrm{pm}$. Williams' Average ${ }^{11,12}$ was used for all three stages, whether capturing with HAT, 15h ST or dST.

As a parameter of the effect of the formation of the lake, the Wealth Index was determined by the number of Anopheles species and the diversity of these by the Brillouin Index ${ }^{13,14}$, for the three locations at different water surface elevations. This index estimates species diversity by measuring individual specimens from each species in each community and incorporates the relative abundance of captured specimens over the series of floods provoked by Porto Primavera Hydro-Power Station. Due to the epidemiological importance, populations of An darlingi, An albitarsis, An triannulatus and An galvaoi were studied.

Comparative analysis was performed by the Mann-Whitney test for the wealth and diversity indices for a level of significance of $p \leq 0.05$, analyzing the distributions of frequencies according to location, surface water elevations and method of capture as independent variables. The analyses were performed using the computer software SPSS, version 12.

\section{RESULTS}

For all stages of mosquito captures the outcome was 102,749 Culicidae specimens, belonging to 11 genera. For the genus Anopheles a total of 23,120 specimens was reported, distributed among 14 species.

The results for wealth and diversity indices, calculated by HAT, regarding stage 1 Anopheles, verified that at location A no statistically significant difference was detected compared to the results for location B. Between stages 1 and 2, a significant difference was verified when comparing the indices for location $\mathbf{B}$ by HAT. This result was repeated when the $15 \mathrm{~h}$ ST method was used. For the final stage of the study, the wealth and diversity indices for locations $\mathbf{B}$ and $\mathbf{C}$ also showed statistically significant differences regarding Anopheles. With the indices calculated using $15 \mathrm{~h} \mathrm{ST}$ for location A in stages 1 and 2, no statistically significant differences were estimated. In stage 3, the captures in wild areas at locations $\mathbf{B}$ and $\mathbf{C}$ showed significant differences, as did the peridomicile (Table 1).

Figure 1 shows curves of different measurements for daily activity of An darlingi by HAT. At location A, the curve was bimodal $(\mathrm{Aa})$ for the period-from $5 \mathrm{pm}$ to $3 \mathrm{am}$ and included a sudden rise from 5 am to $8 \mathrm{am}$. At location $\mathbf{B}\left(\mathrm{Bb}_{1}\right)$, day time activity showed greater values for the years $1997 / 1998$, while for the period $1999 / 2000$, three more clearly defined peaks were detected $\left(\mathrm{Bb}_{2}\right)$. When the $15 \mathrm{~h} \mathrm{ST}$ technique was used, analysis verified that the search activity for a host was continuous, alternating between peaks and temporal stability throughout the night $\left(\mathrm{Bb}_{3}\right.$ and $\left.\mathrm{Bb}_{4}\right)$. At location C, the temporal activity of An darlingi was intense and progressively diminished until 7 am $\left(\mathrm{Cc}_{1}\right)$.

Figure 2 indicates that, in location $\mathbf{A}$ by HAT in stage 1 for An albitarsis, there was basically night activity with a raise in frequency between 2 and 3 am, declining until $7 \mathrm{am}\left(\mathrm{Aa}_{2}\right)$. In location $\mathbf{B}$, the time of activity for the species was shorter, therefore, the maximum peak was between $11 \mathrm{pm}$ and midnight $\left(\mathrm{Bb}_{5}\right)$. 
TABLE 1 - Anopheles adults collected at locations A (State of Mato Grosso do Sul), B and C (State of São Paulo) with Shannon trap, in dawn twilight, between 1998 and 2003.

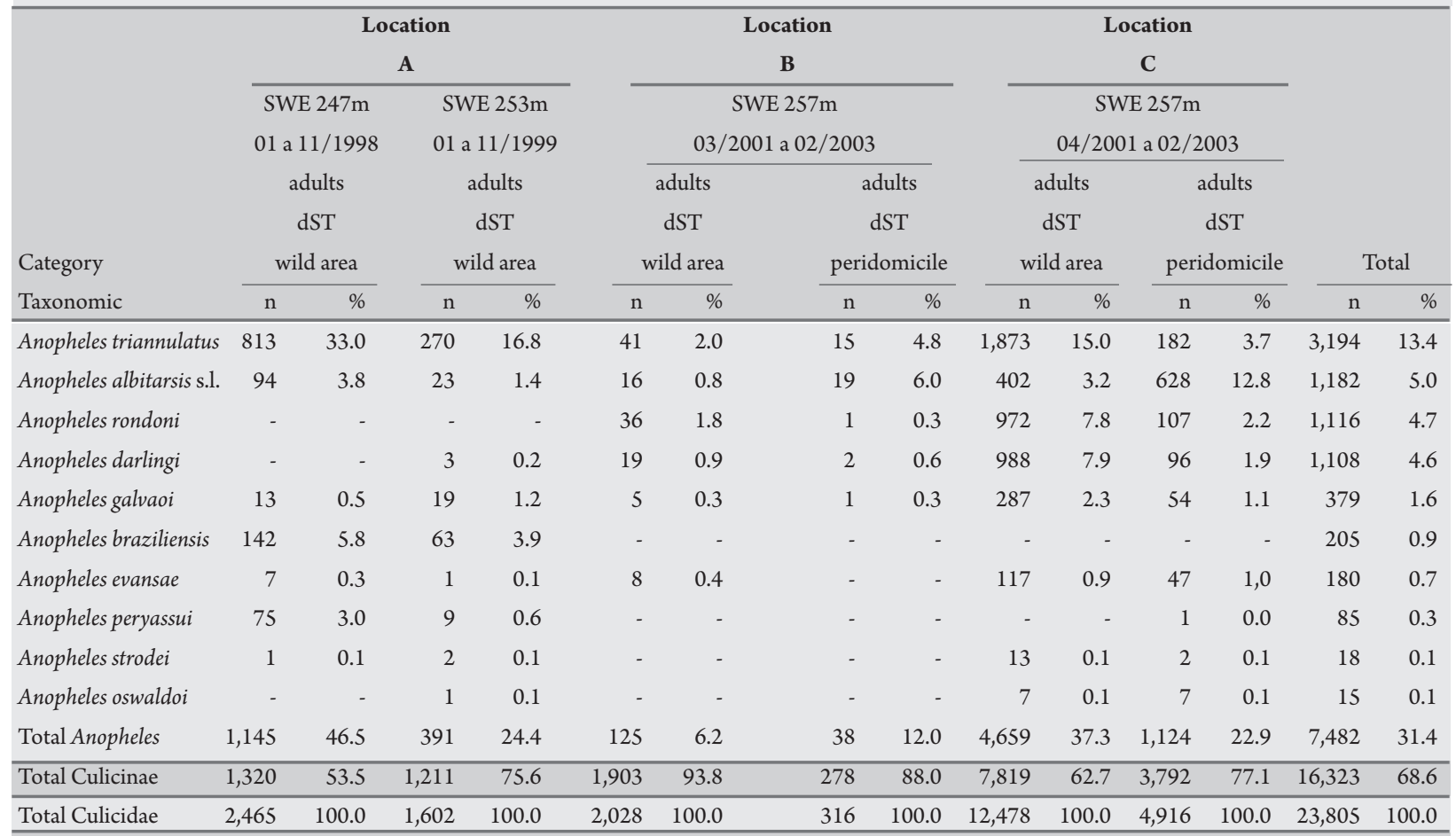

SWE: water surface elevation (m). dST: dawn Shannon trap, s.l.: sensu lato.

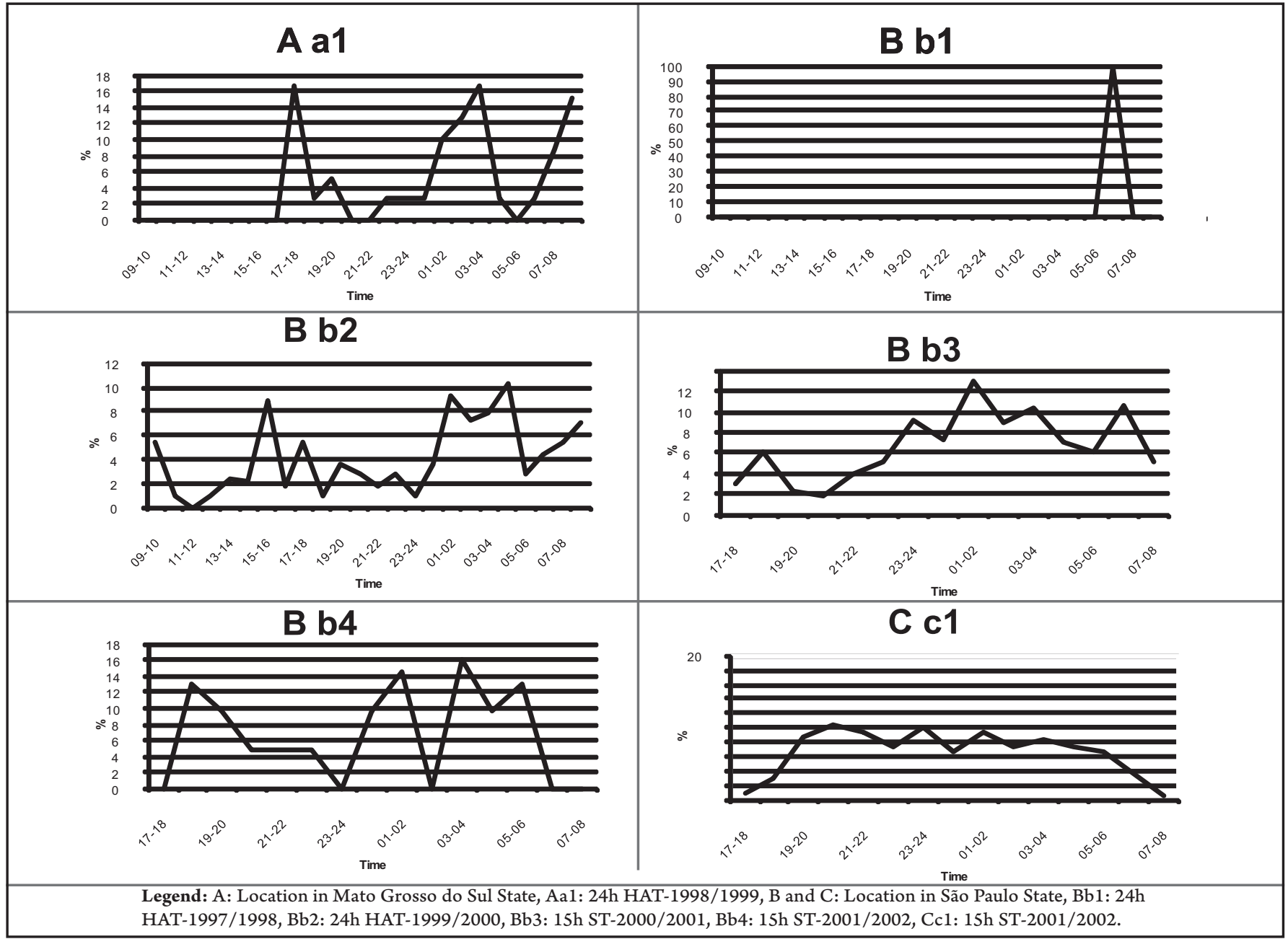

FIGURE 1 - Temporal activity of Anopheles darlingi collected at locations A, in the State of Mato Grosso do Sul, B and C, in the State of São Paulo, for the period between 1997 and 2002, according to specific techniques for adults. 


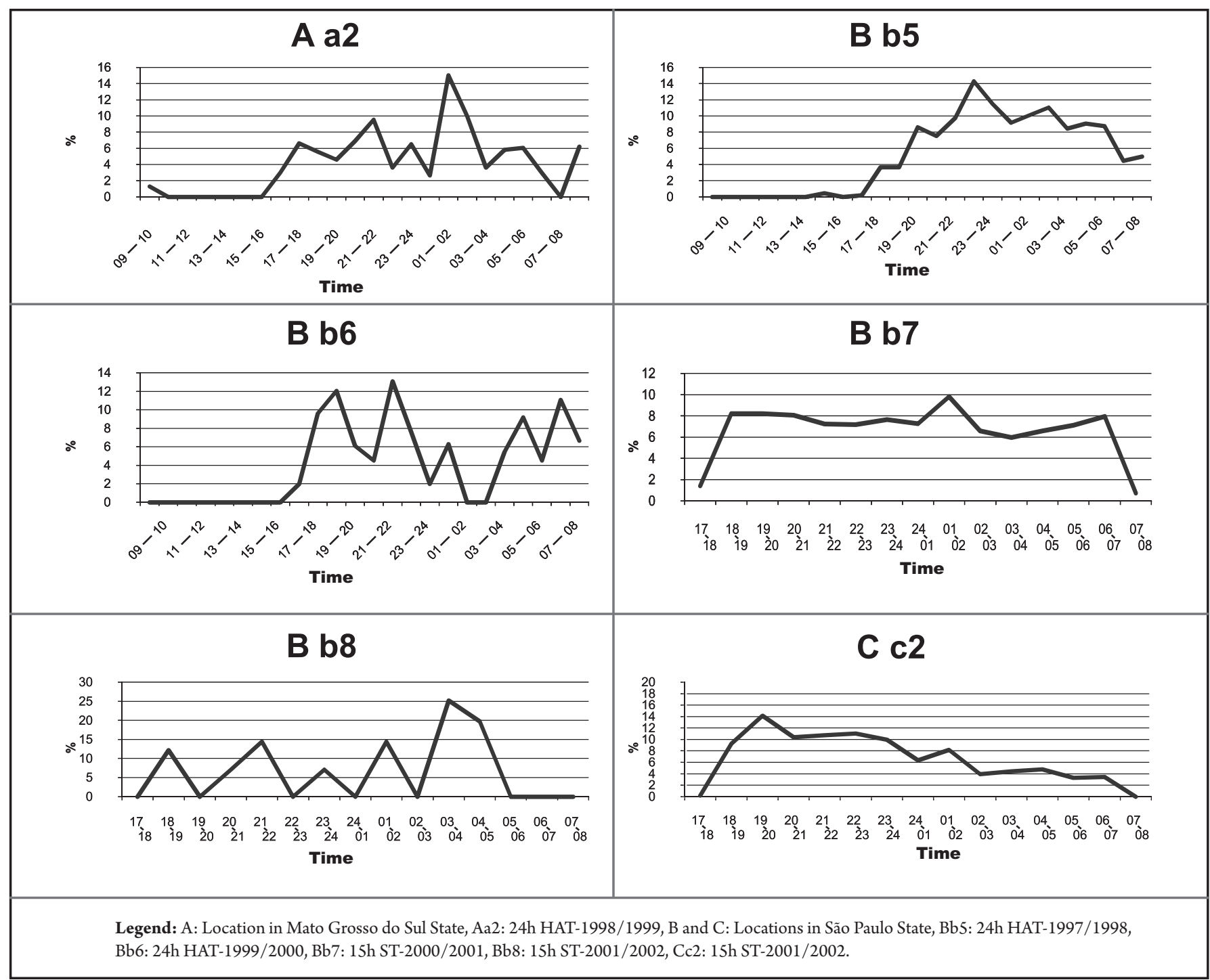

FIGURE 2 - Temporal activity of Anopheles albitarsis s.l. collected at locations A, in the State of Mato Grosso do Sul, B and C, in the State of São Paulo, for the period between 1997 and 2002 , according to specific techniques for adults.

Following stage 2, the oscillations in temporal frequency were intense from $5 \mathrm{pm}$ to midnight, emerging with a minor peak from $7 \mathrm{am}$ to $8 \mathrm{am}\left(\mathrm{Bb}_{6}\right)$. For capture with $15 \mathrm{~h} \mathrm{ST}$ in stage 2 , the curve was atypical $\left(\mathrm{Bb}_{7}\right)$, since after the increase at $5 \mathrm{pm}$, it remained constant throughout the night, with an steady decline from 6 am to $7 \mathrm{am}$; however, in stage 3 , activity was intermittent with greater frequency between 3 and $4 \mathrm{am}\left(\mathrm{Bb}_{8}\right)$. At location $\mathbf{C}$, specimen collection presented a peak from 7 to $8 \mathrm{pm}$, declining from that point to the end of the night $\left(\mathrm{Cc}_{2}\right)$.

At location A, An triannulatus presented frequently during daylight hours, with the highest peak between 6 and 7 pm using HAT, it then declined until 6 am, when there was a discreet increase in activity between 7 and 8 am $\left(\mathrm{Aa}_{3}\right)$ (Figure 3).

At location B, in stage 3, HAT values showed a three-peak curve from 5 to $7 \mathrm{pm}$, from 11 to midnight and between 5 and $7 \mathrm{am}\left(\mathrm{Bb}_{9}\right)$, while in stage 2 the peaks from 6 to 9 pm were highlighted $\left(\mathrm{Bb}_{10}\right)$.
With $15 \mathrm{~h} \mathrm{ST}$, the activity initiated intensively at $5 \mathrm{pm}$, declining progressively until the end of the night $\left(\mathrm{Bb}_{11}\right)$. In stage 3 , the species basically presented a peak of activity at $9 \mathrm{pm}\left(\mathrm{Bb}_{12}\right)$.

At location $\mathbf{C}$, the lowest frequency of this species, was recorded, with only one peak at $10 \mathrm{pm}\left(\mathrm{Cc}_{3}\right)$.

At location A, in stage 1, An. galvaoi presented temporal activity before dawn, with only one peak between 7 and $8 \mathrm{pm}\left(\mathrm{Aa}_{4}\right)$. At location $\mathbf{B}$, the species maintained low hematophagic activity, with discreet peak at $4 \mathrm{am}\left(\mathrm{Bb}_{13}\right)$. In stage 2 , the species became sporadic, with sudden peaks between $7 \mathrm{pm}$ and midnight $\left(\mathrm{Bb}_{14}\right)$ (Figure 4). For the same period, activity measured by $15 \mathrm{~h} \mathrm{ST}$ occurred between $6 \mathrm{pm}$ and midnight $\left(\mathrm{Bb}_{15}\right)$. In stage 3 , the species remained irregular in its activity and was more frequently captured between midnight and $6 \mathrm{am}\left(\mathrm{Bb}_{16}\right)$. At location $\mathbf{C}$, at this dam surface water elevation, the species showed a peak at $7 \mathrm{pm}$, declining steadily throughout the night $\left(\mathrm{Cc}_{4}\right)$. 


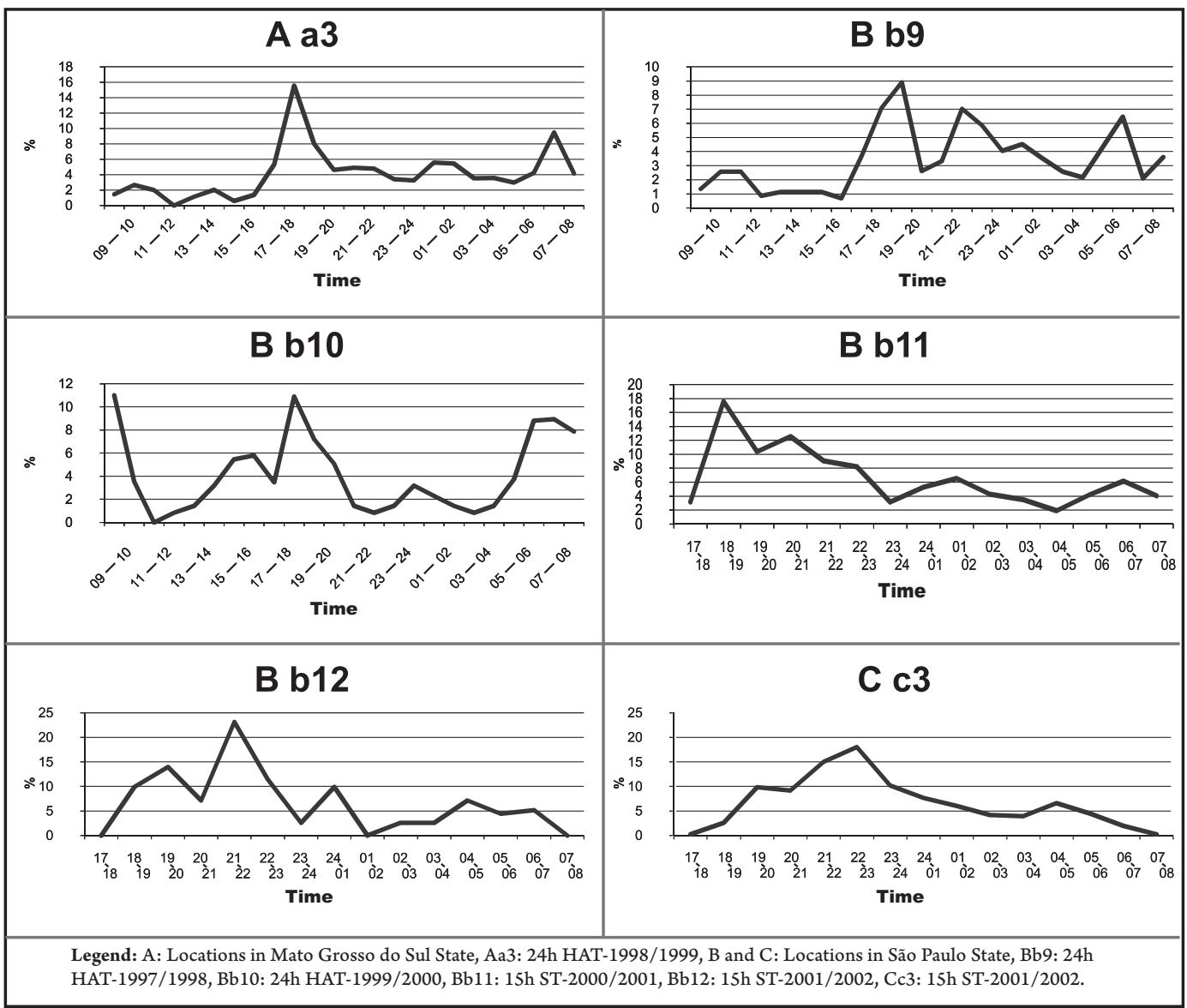

FIGURE 3 - Temporal activity of Anopheles triannulatus collected at locations A, in the State of Mato Grosso do Sul, B and C, in the State of São Paulo, for the period between 1997 and 2002, according to specific techniques for adults.

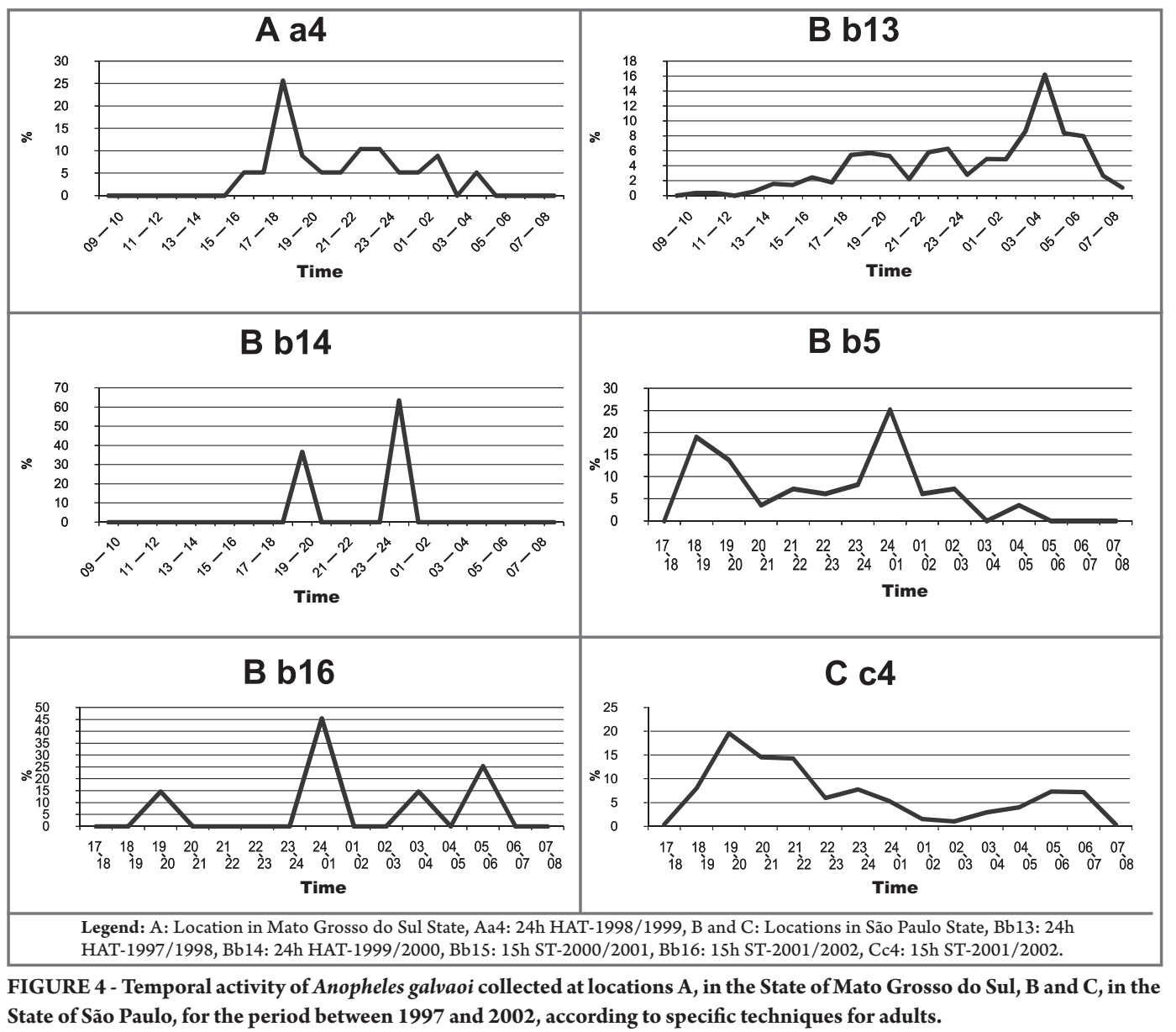




\section{DISCUSSION}

Wealth and diversity were parameters affected by the different stages of construction of the Porto Primavera dam, such that they permitted the classification of the area as steady and unstable. It was obvious that prior to the dam, the behavioral characteristics of An darlingi, An albitarsis s.l., An triannulatus and An galvaoi were associated with local seasonal factors and subsequently, major oscillations occurred in the frequency of specimen captures, with periods of abundance and intermittence. This fact was clearer during the first flood at locations $\mathbf{B}$ and $\mathbf{C}$. Anopheles darlingi showed mostly nocturnal hematophagic habits, but within this period, it can present peaks at different times. Roberts et a ${ }^{15}$ considered the possibility that this species presents hematophagic peaks, depending on the location studied; a fact that suggests each flood event influenced temporal activity independently. This aspect was evident in the study, since the alterations in the dynamic of temporal activity in the populations studied were clearly related to the introduction of environmental changes. This finding is of great importance when developing a program for entomological survey based on the risk of human infections.

Several reports regarding the characteristics of temporal activity of An darlingi revealed a pattern of temporal activity in South America that ranges from unimodal to trimodal ${ }^{15-20}$, bimodal being the most common. In the study area, this last pattern was predominant before the dam project, but was altered following the lake formation.

The phenomenon of flooding usually contains widely distributed anopheles nurseries, as it was the case in the area studied, which has implications concerning the displacement of immature forms spread over the area to other points of the dam or for the remaining adult Anopheles that search for new locations places to form their nurseries, given that the survival of the species depends on adaptation to new habitats. This population disturbance contains the reasons to for the changes in the pattern of temporal activity of Anopheles. According to Charlwood and Wilkes ${ }^{21}$, this characteristic seems to depend on the interrelationship between several local ecological factors and the target species. Assuming this is true, it affirms that the bimodal pattern of activity of An darlingi would have to change because of the dam construction, in response to alterations in the ecological conditions. Regarding the maintenance of vector status for An darlingi and for other Anopheles, this will depend on the aptitude of each species, as to whether the inherited characteristics of these populations will permit the return of the population dynamic of the temporal activity when ecological conditions stabilize ${ }^{21}$.

One aspect that proved to be resistant to the recent changes was the pre twilight activity of Anopheles in different observation times. For both An darlingi and An albitarsis s.1., this was similar to that reported for Suriname ${ }^{5}$. Since the extension of temporal activity in the predawn and post morning occurred for a short period of time, it was assumed that this behavior was the result of a certain number of females that had not fed during the previous night initiating the hematophagic cycle earlier. This supposition finds support in the work by Charlwood ${ }^{22}$, in Aripuanã, where $64.4 \%$ of An darlingi females captured between $6 \mathrm{pm}$ and $7 \mathrm{pm}$ were nuliparous, while from $7 \mathrm{pm}$ to 5:30 am an inversion occurred, with only $39 \%$ of the same and from 5:30 am to $6 \mathrm{am}, 71 \%$ were nuliparous females. Thus, these females compose the surplus hungry females from the previous night.

The format of the temporal activity curves of Anopheles measured by HAT and ST attracted our attention. The first observation is that the peaks shown by HAT were almost always distinct and well defined, while that not always true for ST. One explanation for this divergence concerns the specificity of each method, since the attraction of the first is based solely on the degree of species anthropophilia, while in the second method, the multiple attractions (light, heat, human presence and other factors) attracted more population segments. In other words, capture with ST involves specimens of all ages and physiological stages and total would result in the format of a distinct curve and not a peak with few population segments. Therefore, these elements must be considered when interpreting the results by ST, since they are quite distinct from considering alternations in time when visualization of the activity is specific to a group or formed by a population. Furthermore, the offer of greater surface area for landings and simulations of shelter must be added to the previous factors that make ST an eclectic capture method of Anopheles.

Analysis concerning the behavior of An albitarsis s.l. revealed that the divergence in times for these activities suffered the same influences as the factors determined by the dam; however, in relation to An darlingi, the tendency for a unimodal pattern seems to be determinant. Klein \& Lima $^{19}$ recorded a peak that coincided with this observation. Anopheles triannulatus was a common species in the locations studied revealing the habit of search for a host at certain times of the day, making it possible to classify this behavior as an intrusion effect ${ }^{23}$. Considering these changes, the nocturnal period showed more intense activity, when the peaks of greatest frequency presented in bimodal and trimodal forms. For Anopheles galvaoi, temporal activity underwent strong alteration with the dam formation; though the tendency observed was single peaks from $6 \mathrm{pm}$ to $8 \mathrm{pm}$ and from $4 \mathrm{am}$ to 6 am, both related to twilight and dawn ${ }^{24}$.

In the scenario created by the construction of the Porto Primavera Hydro-Power Station different levels of environmental changes were associated with differentiated impact on temporal activity, as a result of alterations in Anopheles diversity. The disproportionality of action on the hematophagic cycles of primary and secondary vectors of malaria is the response to each of the interventions that occurred in the environment where the dam was constructed. This knowledge is useful for promoting protective actions for all people who live in or travel to the area for leisure, in that specific programs to protect against malaria can be developed, which consider the differences in epidemiological risk inherent in in steady and unstable ecological conditions in this area. The findings of this study were only possible due to the longitudinal study, which are rare for most hydroelectric power stations in Brazil.

\section{ACKNOWLEDGMENTS}

The authors would like to thank systems analyst Fernão Dias de Lima for his assistance during the statistical analyses and computer technician Rodrigo Alexandre Sportello for the graphics structure support.

\section{CONFLICT OF INTEREST}

The authors declare that there is no conflict of interest.

\section{FINANCIAL SUPPORT}

Fundação de Amparo à Pesquisa do Estado de São Paulo (FAPESP), Brasil (96/10014-1; 99/11377-9). Field logistics: Companhia Energética de São Paulo (CESP). 


\section{REFERENCES}

1. Vittor AY, Gilman RH, Tielsch J, Glass G, Shields T, Lozano WS, et al. The effect of deforestation on the human-biting rate of Anopheles darlingi, the primary vector of falciparum malaria in the Peruvian Amazon. Am J Trop Med Hyg 2006; 74:3-11.

2. Gomes ECS, Albuquerque CMR, Souza JRB, Arruda ME, Confalonieri UEC. Structure of Anopheles (Diptera: Culicidae) population in areas with different degrees of human settlement: Cantá-Roraima-Brasil. Acta Amaz 2008; 38:321-329.

3. Quintero LO, Thatcher BD, Tadei WP. Biologia de anofelinos amazônicos. XXI. Ocorrência de espécies de Anopheles e outros culicídeos na área de influência da hidrelétrica de Balbina - Cinco anos após o enchimento do reservatório. Acta Amaz 1996; 26:281-296.

4. Tadei WP, Thatcher BD, Santos JMM, Scarpassa VM, Rodrigues IB, Rafael MS Ecologic observations on anopheline vectors of malaria in the Brazilian Amazon. Am J Trop Med Hyg 1998; 59:325-335.

5. Rozendaal JA. Biting and resting behavior of Anopheles darlingi in the Suriname Rainforest. J Am Mosq Control Assoc 1989; 5:351-358.

6. Forattini OP. Culicidologia médica. São Paulo: Editora da Universidade de São Paulo; 2002. v. 2.

7. Santos RC, Forattini OP. Marcação-soltura-recaptura para determinar o tamanho da população natural de Anopheles albitarsis s.l. (Diptera: Culicidae). Rev Saude Publica 1999; 33:309-313.

8. Rachou RG. Anofelinos no Brasil: comportamento das espécies vetoras de malária. Rev Bras Malariol Doenças Trop 1958; 10:145-181.

9. Gomes AC, Paula MB, Duarte AMRC, Lima MA, Malafonte RS, Mucci LF, et al. Epidemiological and ecological aspects related to malaria in the area of influence of the lake at Porto Primavera dam, in western São Paulo State, Brazil. Rev Inst Med Trop Sao Paulo 2008; 50:287-295.

10. Paula MB, Gomes AC. Culicidae (Diptera) em área sob influência de construção de represa no Estado de São Paulo, Brasil. Rev Saude Publica 2007; 41:284-289.

11. Haddow AJ. Studies on the biting-habits on African mosquitoes: an appraisal of methods employed, with special reference to the twenty-four-hour catch. Bull Entomol Res 1954; 45:199-242.

12. Haddow AJ. Studies on the biting-habits and medical importance of east African mosquitoes in the genus Aedes. I-Subgenera Aedimorphus, Banksinella and Dunnius. Bull Entomol Res 1960; 50:759-779.

13. Johnson MF, Gómez A, Pinedo-Vasquez M. Land use and mosquito diversity in the Peruvian Amazon. J Med Entomol 2008; 45:1023-1330.

14. Magurran AE. Ecological diversity and its measurement. Cambridge: University Press; 1988.

15. Roberts DR, Alecrin WD, Tavares AM, Radke MG. The house-frequenting, hostseeking and resting behavior of Anopheles darlingi in Southeastern Amazonas, Brazil. J Am Mosq Control Assoc 1987; 3:433-441.

16. Charlwood JD, Hayes J. Variações geográficas no ciclo de picada do Anopheles darlingi Root no Brasil. Acta Amaz 1978; 8:601-603.

17. Forattini OP. Comportamento exófilo de Anopheles darlingi Root, em região meridional do Brasil. Rev Saude Publica 1987; 21:291-304.

18. Hudson JE. Anopheles darlingi Root (Diptera: Culicidae) in the rainforest. Bull Entomol Res 1984; 74:129-142.

19. Klein TA, Lima JBP. Seasonal distribution and biting patterns of Anopheles mosquitoes in Costa Marques, Rondonia, Brasil. J Am Mosq Control Assoc 1990; 6:700-707

20. Rosa-Freitas MG, Broomfield G, Priestman A, Milligan PJ, Momen H, Molyneux DH. Cuticular hydrocarbons, Isoenzymes and behavior of three populations of Anopheles darlingi from Brazil. J Am Mosq Control Assoc 1992, 8:357-366.

21. Charlwood JD, Wilkes TJ. Studies on the age-composition of samples of Anopheles darlingi Root (Diptera: Culicidae) in Brazil. Bull Entomol Res 1979; 69:337-342.

22. Charlwood JD. Observation on the bionomics of Anopheles darlingi Root (Diptera: Culicidae) from Brazil. Bull Entomol Res 1980; 70:685-692.
23. Forattini OP, Gomes AC, Santos JLF, Galati EAB, Rabello EX, Natal D. Observações sobre atividade de mosquitos Culicidae em mata residual no Vale do Ribeira, São Paulo, Brasil. Rev Saude Publica 1981; 15: 557-586.

24. Guimarães AE, Mello RP, Lopes, CM, Alencar J, Gentile, C. Prevalência de anofelinos (Diptera: Culicidae) no crepúsculo vespertino em áreas da usina hidrelétrica de Itaipu, no município de Guairá, Estado do Paraná, Brasil. Mem Inst Oswaldo Cruz 1997; 92:745-754. 